\title{
Some effects of precipitation patterns on mesa dropseed phenology
}

\author{
ROBERT P. GIBBENS
}

\begin{abstract}
Phenology of mesa dropseed [Sporobolus flexuosus (Thurb.) Rydb.] was studied from 1979 to 1987 on the Jormada Experimental Range in southern New Mexico. Growing season (March through November) precipitation ranged from 99 to $308 \mathrm{~mm}$ during the 8-year period. Foliage height and number of leaves were recorded weekly for individually marked culms on 20 plants. New culms usually appeared during the first week in March and green leaf tissue often persisted until the end of November. Correlation analyses of accumulated weekly height increments and accumulated weekly precipitation showed that growth was highly dependent upon rainfall $(r=0.81$ to 0.97$)$. Leaf formation was also correlated with rainfall $(r=0.79$ to 0.98$)$. Even in relatively wet years there were 1 or 2 periods of no growth. In drier years, no growth periods totaled as much as 87 days. Periods of rapid growth occurred only after rainfall events $>13 \mathrm{~mm}$. The first exsertion of seed heads occurred as early as the last week of July and as late as the second week of October. The temporal plasticity of mesa dropseed phenology indicates that it is well adapted to the arid environment.
\end{abstract}

Key Words: grass growth, leaf development, arid zones, rangeland, Sporobolus flexuosus, Chihuahuan Desert

An understanding of plant phenology, or the temporal occurrence of growth phases, is basic to sound resource management, e.g., determination of range readiness and development of geographically oriented resource management models (Costello 1939,

\footnotetext{
Author is range scientist, Jornada Experimental Range, Agricultural Research Service, USDA, P.O. Box 30003, Dept 3JER, New Mexico State Univ., Las Cruces 88003.

The use of trade names does not constitute an official endorsement or approval by the United States Department of Agriculture.

Appreciation is expressed to Dr. John T. Hennessy who assisted in data collection in 1979 and 1980 and to James $M$. Lenz who assisted in subsequent years.

Manuscript accepted 19 May 1990.
}

Lieth and Radford 1971). The relatively recent development of methods for quantifying phenological observations (West and Wein 1971, Haun 1973) increases their utility in resource management applications.

Much phenological research has been concerned with the influence of climatic variables upon crop plants (Abbe 1905, Thornthwaite 1952) and upon regional responses of selected indicator species (Gilbert 1961, Caprio 1966). Phenological studies of weed species have been made so that optimum timing of control measures could be achieved (Finnerty and Klingman 1962, McCarty and Scifres 1969, Hyder et al. 1962, Young and Evans 1974, Roundy et al. 1981). Comparative phenological development of species in native plant communities has received considerable attention (Ahlgren 1957, Ahshapanek 1962, Hulbert 1963, Dickinson and Dodd 1976, McCarty 1986).

Many studies have related phenological phases to accumulated degree days or solar-thermal units (Caprio 1971, White 1979, Frank and Hofmann 1989). However, in desert areas precipitation has been found to be the critical factor in plant phenology (Went 1949, Beatley 1974). The purpose of this study was to determine the effect of precipitation patterns on the growth and development of mesa dropseed [Sporobolus flexuosus (Thurb.) Rydb.], an important forage species in the northern Chihuahuan Desert.

\section{Materials and Methods}

This study was conducted on the Jornada Experimental Range (JER) $37 \mathrm{~km}$ north of Las Cruces, New Mexico. The 78,266-ha JER lies principally on undulating plains of the closed Jornada Basin at an elevation of about $1,260 \mathrm{~m}$. Mean monthly maximum temperatures are highest in June $\left(36^{\circ} \mathrm{C}\right)$ and lowest in January $\left(13^{\circ} \mathrm{C}\right)$. Long-term average annual precipitation is $230 \mathrm{~mm}$ with $52 \%$ occurring in July, August, and September. Summer precipita- 
tion is mostly from high intensity, short-duration, convective storms covering small areas. Winter precipitation comes from low-intensity frontal storms covering broad areas. Snow is infrequent. The frost-free period averages $\mathbf{2 0 0}$ days, but the effective growing season, when soil water and temperature are favorable, is often 90 days or less (Paulsen and Ares 1962).

The Jornada basin was formerly dominated by black grama [Bouteloua eriopoda (Torr.) Torr.]; but shrubs, e.g., honey mesquite (Prosopis glandulosa Torr.), creosote bush [Larrea tridentata (DC.) Cov.], and tarbush (Flourensia cernua DC.), now dominate most of the basin (Buffington and Herbel 1965). With the breakup of the black grama stands, mesa dropseed, a relatively short-lived perennial grass which reproduces readily from seed, has become a dominant species and a major source of forage (Paulsen and Ares 1962).

Phenological observations of mesa dropseed began in 1979 and continued through 1987 . In 1979 and 1980, observations were made at 2 sites ( $A$ and $B$ ). In 1981, observations were made only at site A. Because of the termination of other studies at sites A and B and to conserve travel time, observations were moved to a new site (C) in 1982 and continued at this site through 1987. Observations were also made at a fourth site (D) from 1985 to 1987. Site A was 5 $\mathrm{km}$ from site $B$ and site $C$ was $17 \mathrm{~km}$ from site $D$.

Soils of the study sites were sandy loams or loamy sands and included coarse-loamy, mixed, thermic Typic Calciorthids of the Wink series (site A), coarse-loamy, mixed, thermic Typic Haplar- gids of the Onite series (sites B and D), and loamy, mixed, thermic, shallow Typic Paleorthids of the Simona series (site C) Bullock and Neher 1980).

At each site, 20 randomly selected plants were marked with numbered stakes. Each season, 1 emerging culm on each plant was marked with colored electrical wire. Extended foliage height of the marked culm was measured weekly. Emergence of all leaves on marked culms was rated on a 10-point scale from 0 to 1 , with 0.1 denoting the appearance of the tip of the leaf and 1 denoting the appearance of the ligule from the subtending sheath. Thus, by summing the number of wholly and partially emerged leaves for each culm, a leaf emergence number or index was obtained weekly. Phenological events such as inflorescence emergence, flowering, and seed fall, also were rated on a 10-point scale. In 1979 and 1980 , drying of individual leaves was not recorded and observations were terminated after growth had ceased. In subsequent years, drying of individual leaves on marked culms was rated on a 10-point scale and observations continued until no, or very little, green tissue was present. Periods of no growth were defined as those when average leaf and height growth did not increase more than 0.05 leaf emergence units and $0.05 \mathrm{~cm}$, respectively.

The plants were within livestock exclosures but experienced herbivory by insects, rodents, and lagomorphs (large native ungulates did not use the areas). Fences of $2.54-\mathrm{cm}$ mesh were erected around plots after 1981 in an attempt to reduce lagomorph grazing but were only partially successful. When a marked culm was grazed

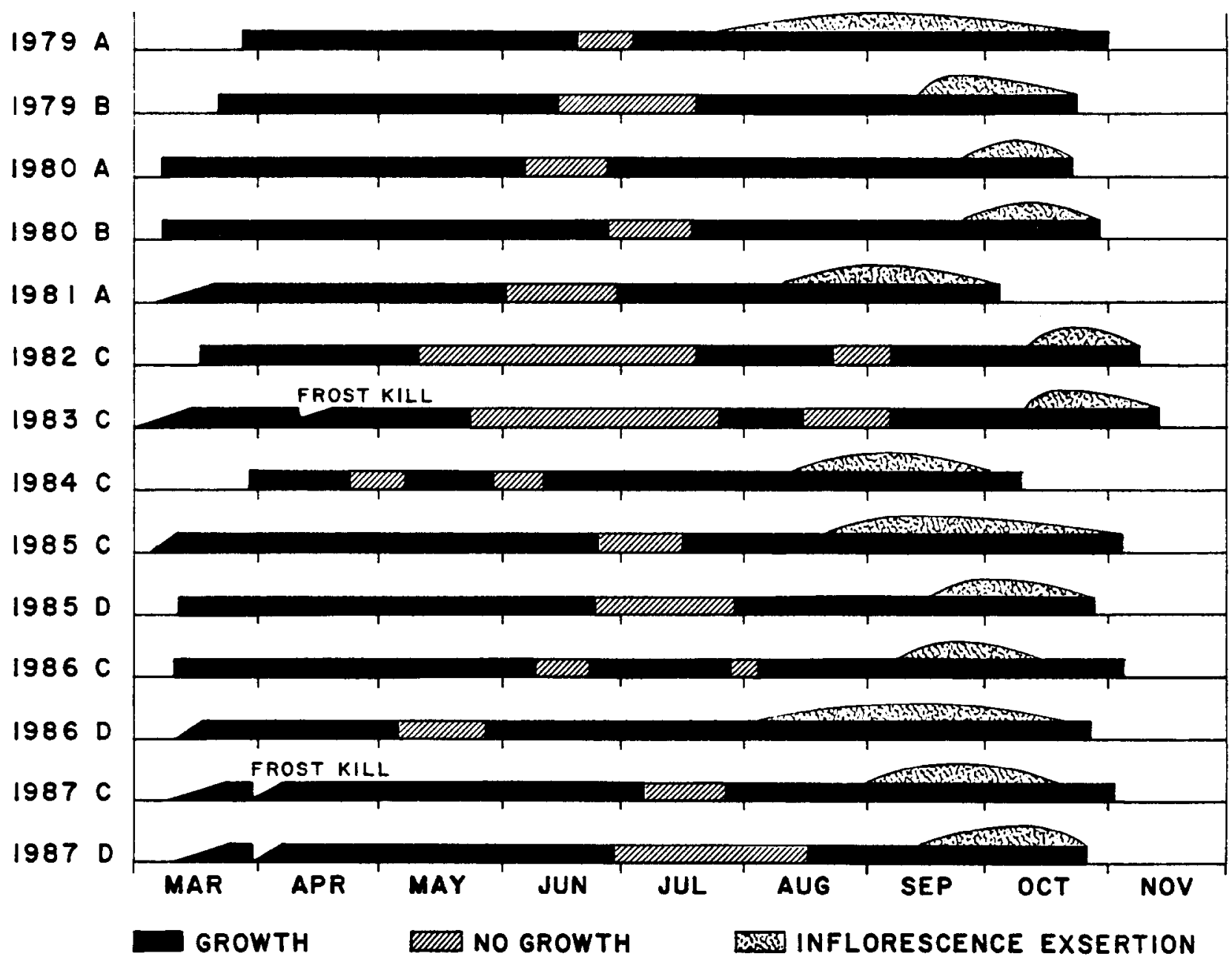

Fig. 1. Periods of growth, no-growth and inflorescence exsertion for mesa dropseed during a 9-year period at 4 sites in southern New Mexico. All plants did not have emerged culms until growth bars achieve full width. Period of maximum inforescence exsertion is indicated by maximum bar width. 
or the growing point damaged by insects, a new culm was marked. This meant that the number of culms from which an average weekly growth increment could be obtained was usually less than 20 . The level of herbivory was so high that rarely was it possible to observe a given culm throughout the season.

Belfort, weighing-type, recording-rain gauges were maintained at all study sites. Correlation and regression analyses were used to determine relationships between accumulated weekly height increments, accumulated weekly increases in number of leaves, and accumulated weekly precipitation. Statistical significance was assumed at $P \leq 0.05$. The rainfall accumulation period extended from the day following one plant measurement date up to and including the next measurement date. To see if there was a delay in plant response to rainfall inputs, the rainfall accumulation period was lagged from 1 through 5 days, i.e., the last day of rainfall accumulation was the day prior to plant measurements, 2 days prior to measurement, etc., up to 5 days (the minimum measurement interval).

\section{Results and Discussion}

New tillers or culms of mesa dropseed usually originated from basal buds below ground level, although occasionally a bud at an elevated node initiated a new culm. New culms usually began to appear during the first week of March but there was considerable variation among plants and years. For example, in 1980 all marked plants had emerged culms on 7 March; in 1983, 55\% of marked plants had emerged culms on 1 March but not all plants until 14 March. In 1987, new culms were present on $50 \%$ of the plants on 9 March but culms did not emerge on all plants until 23 March (Fig. 1). Minimum temperatures were often below freezing in March, and in $198350 \%$ of marked culms were killed by frost (Fig. 1). On 30 March 1987, the minimum temperature recorded at the JER headquarters was $-9^{\circ} \mathrm{C}$ (NOAA 1987). All culms were killed by the freeze (Fig. 1) but the plants immediately initiated new culms and a new set was marked for observation on 6 April.

There was a great deal of variability in precipitation within and among years and among sites (Table 1). One might expect that

Table 1. Precipitation during December to February and during March to November at the study sites in southern New Mexico.

\begin{tabular}{llcc}
\hline \hline Year & Site & Dec-Feb & Mar-Nov \\
\hline & & & $-\mathrm{mm}-$ \\
1979 & A & 61 & \\
1979 & B & 60 & 203 \\
1980 & A & 40 & 165 \\
1980 & B & 73 & 186 \\
1981 & A & 26 & 139 \\
1982 & C & 16 & 235 \\
1983 & C & 76 & 99 \\
1984 & C & 8 & 161 \\
1985 & C & 77 & 297 \\
1985 & D & 99 & 289 \\
1986 & C & 10 & 232 \\
1986 & D & 12 & 268 \\
1987 & C & 54 & 308 \\
1987 & D & 56 & 243 \\
\hline
\end{tabular}

winter precipitation (December to February) would have some effect upon spring growth. However, regression of accumulated leaf and height increments upon December-February precipitation at 4,6 , and 8 weeks following culm initiation revealed a very weak relationship ( $P \geq 0.05$ ). Coefficients of determination $\left(R^{2}\right)$ for height did not exceed 0.1 and number of leaves present had a maximum $R^{2}$ of 0.18 at 8 weeks.

Precipitation during the growing season (March to November) was highly variable among years, ranging from 99 to $308 \mathrm{~mm}$ (Table 1). Temporal distribution of precipitation within seasons varied greatly and had a pronounced effect upon the growth of mesa dropseed. In every year there were periods when growth of the plants was arrested, apparently by lack of soil water. Among years, the periods of arrested growth varied widely and occurred from April through September, although they were concentrated in June and July (Fig. 1). No-growth periods were especially pronounced in 1982 and 1983, when they totaled 86 and 87 days, respectively. In 1982 , during the 10 May- 19 July period, $55 \%$ of the study plants had no green culms for part of the period and the plants were essentially dormant. This early drought was broken by a series of small rainfall events (none larger than $6 \mathrm{~mm}$ ) which began on 21 July and continued intermittently until 5 August. Rapid growth did not occur until after a 21-mm rainfall event on 9 September. In 1983, rapid growth did not occur until after precipitation events of 4 and $15 \mathrm{~mm}$ on 7 and 9 September, respectively. The effect of individual rainfall events upon height growth of mesa dropseed is illustrated in Fig. 2 for a relatively dry (1982) and wet (1985) year.

For all years and sites, growth was most rapid after rainfall events $>13 \mathrm{~mm}$. Studies of soil water regimes of loamy sands and sandy loams on the JER showed that daily precipitation $<13 \mathrm{~mm}$
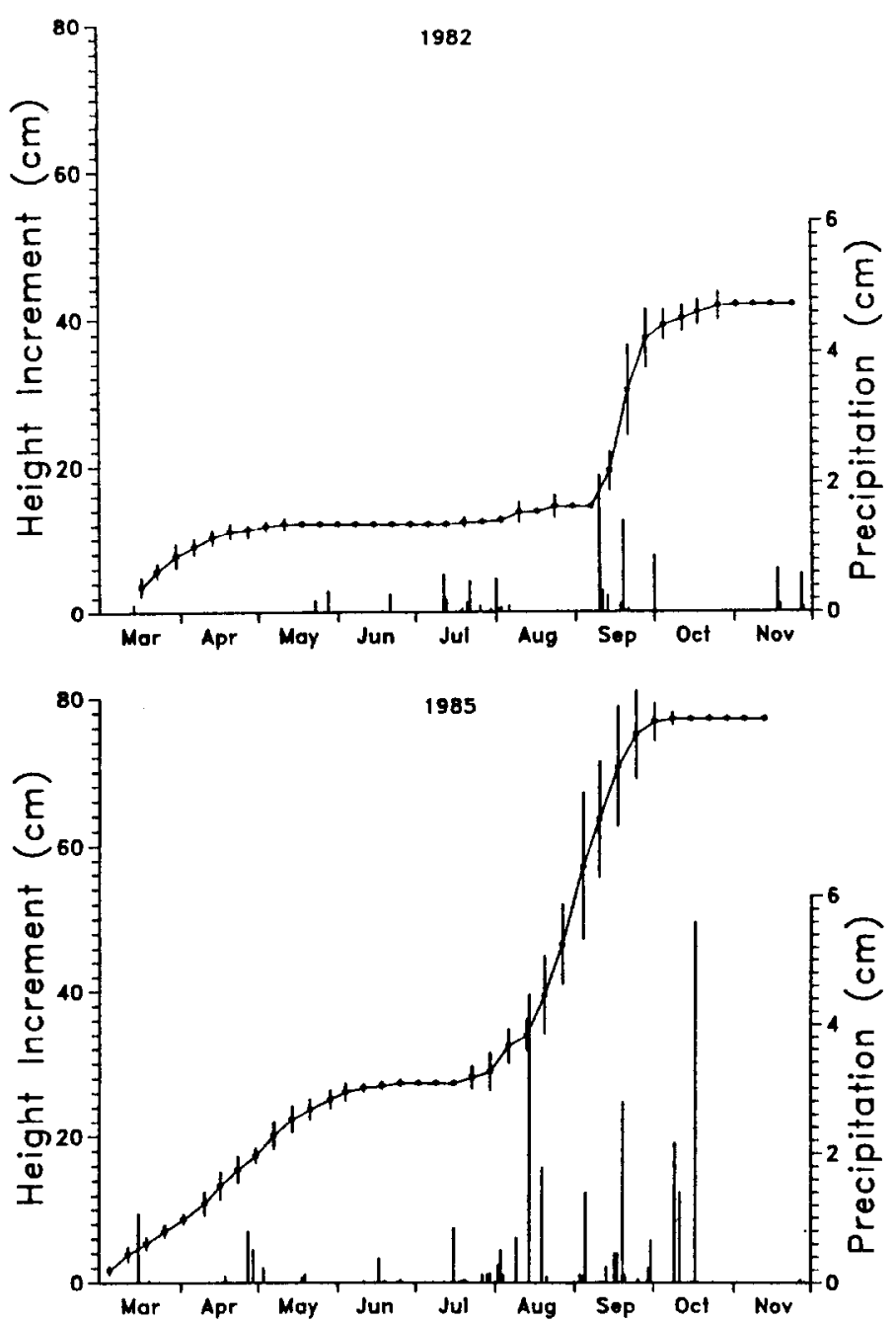

Fig. 2. Accumulated weekly height increments of mesa dropseed and daily precipitation during a relatively dry (1982) and wet (1985) year. Vertical lines on height curves denote \pm 1 standard deviation. 
did not contribute to soil water at depths $>10 \mathrm{~cm}$ (Herbel and Gibbens 1987). Thus, it appears that mesa dropseed growth is most rapid following rainfall events which will supply soil water at depths below $10 \mathrm{~cm}$. Chu et al. (1979) showed that a perennial form of Bromus catharticus Vahl. subjected to water deficits lasting 10 to 28 days produced $48 \%$ more leaves than controls which were watered daily. The rapid growth rates of mesa dropseed following major rainfall events indicate a similar response may occur.

Typically, the first leaf produced on a mesa dropseed culm was short $(0.7$ to $5 \mathrm{~cm}$ ) and the leaves became progressively longer (up to $40 \mathrm{~cm}$ ) until the 4 th or 5 th leaf was produced. The number of leaves on culms producing inflorescences varied from 4 to 15 but the mode was 7 . The first leaves to emerge usually died by midseason and it was not unusual for all leaves to die by the time the inflorescence had completed exsertion. An example of the cumulative weekly leaf increment and the percentage of dead (or missing) leaves is shown in Figure 3. The bimodal curve of dead leaf percentage is typical; the percentage of dead leaves increases during

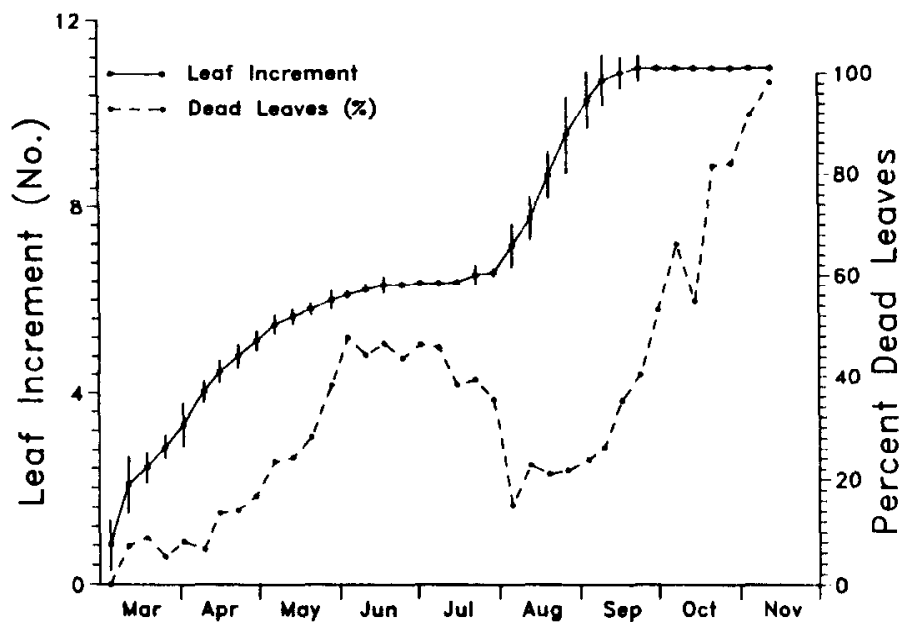

Fig. 3. Accumulated weekly leaf increments and percentage of dry (or mising) leaves of mesa dropseed in southern New Mexico at each sampling date in 1985. The decline in percentage of dry leaves in October was caused by the loss of culms to herbivory and the substitution of culms with different numbers of leaves rather than to production of new leaves. Vertical lines on height curve denote \pm 1 standard deviation.

no-growth periods, declines during periods of rapid growth, and then increases until the end of the season. Rains that fell in late October or November did not result in new leaf production, even on vegetative culms. Late rains did slow leaf drying and green tissue persisted longer in years when such rains occurred.

No attempt was made to determine when growing points changed from the vegetative phase to the reproductive phase. In several perennial grasses, c.g., big bluestem (Andropogon gerardi Vitman) and switchgrass (Panicum virgatum L.), this transition occurs several weeks before inflorescences begin to exsert from subtending sheaths (Rice 1950). Inflorescence exsertion began as early as 24 July (1979, site A) and as late as 11 October (1982, site C) (Fig. 1). There was a large difference in inflorescence emergence times between A and B in 1979 (Fig. 1). Site B received $38 \mathrm{~mm}$ less rainfall than site $A$ (Table 1$)$. Also, site $B$, which had been sprayed with 2,4,5-T [(2,4,5-trichlorophenoxy) acetic acid] for mesquite control in 1975, 1976, and 1977, developed an extremely dense stand of annuals in 1979, and I believe the competition for soil water possibly contributed to the delay in inflorescence exsertion. Annuals were not abundant at site $A$.

Usually only 1 inflorescence was produced per culm although occasionally 1 or 2 secondary inflorescences were produced. This occurred only in years with favorable rainfall patterns, e.g., 1985 , when about $10 \%$ of the culms produced secondary inflorescences. Nodes from which secondary inflorescences originated varied from 3 to 11 but the most common nodes of origin were 4,5 , and 6 . In dry years, e.g., 1982 and 1983, few culms produced inflorescences and none exserted fully. Growing conditions determine whether vegetative or reproductive parts are produced by developing phytomers (Evans 1940). Mesa dropseed responded similarly to Arizona cottontop [ Trichachne californica (Benth.) Chase] (Cable 1971), continuing to producing inflorescences late in the fall, if soil water was available. Most of the late season inflorescences did not fully exsert.

Flowering usually began 4 to 5 days after inflorescences began to exsert. Weekly observations were not sufficiently frequent to fully document flowering periods. It was not unusual for seeds to be formed on the upper part of an inflorescence before the lower inflorescence branches had exserted. Seed shatter was usually completed on all inflorescences by mid-to-late November.

Correlation coefficients between accumulated weekly rainfall and accumulated height and leaf indices were significant $(P \leq 0.05)$ and relatively high (Table 2). This emphasizes the dependence of

Table 2. Correlation coefficients ( $r$ ) for correlations between accumulated weekly leaf increment and accumulated weekly precipitation and between accumulated culm height and accumulated weekly precipitation for mesa dropseed in southern New Mexico. Number of weeks included in analyses are given.

\begin{tabular}{lllccc}
\hline Year & Site & Weeks & $\begin{array}{c}\text { Accumulated } \\
\text { leaf index }\end{array}$ & $\begin{array}{c}\text { Accumulated } \\
\text { culm height }\end{array}$ \\
\hline & & & & - r - & \\
1979 & A & 29 & 0.95 & 0.97 \\
1979 & B & 29 & 0.84 & 0.81 \\
1980 & A & 34 & 0.79 & 0.83 \\
1980 & B & 34 & 0.89 & 0.96 \\
1981 & A & 31 & 0.97 & 0.96 \\
1982 & C & 35 & 0.93 & 0.95 \\
1983 & C & 38 & 0.92 & 0.91 \\
1984 & C & 29 & 0.98 & 0.96 \\
1985 & C & 36 & 0.89 & 0.95 \\
1985 & D & 34 & 0.95 & 0.96 \\
1986 & C & 35 & 0.96 & 0.95 \\
1986 & D & 34 & 0.98 & 0.98 \\
1987 & C & 35 & 0.94 & 0.92 \\
1987 & D & 34 & 0.91 & 0.87 \\
\hline
\end{tabular}

plant growth upon summer rainfall. The relatively low correlation coefficients for site B in 1979 may have resulted from the competition from annual plants mentioned above. The low correlation coefficients for site $A$ in 1980 may have resulted from the lack of large rainfall events. During July, August, and September 1980 the largest daily rainfall amount was $10 \mathrm{~mm}$. In other words, there were no rainfall events that caused a marked increase in plant growth rate. When rainfall accumulation periods were lagged 1 to 5 days the maximum increase in correlation coefficients was only 0.02 , indicating that plant response to rainfall inputs was quite rapid.

\section{Conclusions and Management Implications}

To be successful in the environment of the northern Chihuahuan Desert, a species must be able to cope with extended periods of intra-seasonal drought. The temporal plasticity of mesa dropseed phenology indicates that it is well adapted to its environment. Although growth responses in wet and dry years were compared in this study, it must be emphasized that both wet and dry years are part of the normal, long-term weather pattern in the northern 
Chihuahuan Desert.

Livestock graze mesa dropseed throughout the year but only during the green forage period is protein content high enough to meet animal requirements (Nelson et al. 1970). The spring months in the northern Chihuahuan Desert are often a period of critical shortage of green forage for grazing animals (Paulsen and Ares 1962). Although mesa dropseed begins growth early in the spring, it does not provide much available forage because the first leaves are relatively short and often protected by culms of the previous season. Also, as shown by this study, there is a high frequency of drought-induced periods of no-growth during spring and early summer. Thus, range managers cannot count on mesa dropseed as a forage resource until 1 or 2 weeks after significant rainfall events $(>13 \mathrm{~mm})$. To take full advantage of mesa dropseed forage, range managers need to pay close attention to the temporal and spatial distribution of summer rains and adjust stocking density and distribution accordingly. The goal should be to utilize mesa dropseed as much as possible consistent with maintaining plant vigor and permitting some seed production because, in the long-term, it is a transient forage resource. Severe droughts, such as occurred in the 1950's, result in the virtual disappearance of mesa dropseed on many sites; however, mesa dropseed reproduces readily from seed and can recover quickly from droughts (Herbel et al. 1972).

\section{Literature Cited}

Abbe, C. 1905. A first report on the relations between climates and crops. USDA Bull. 36, Weather Bur. 342.

Ahlgren, C.E. 1957. Phenological observations of nineteen native tree species. Ecology 38:622-628.

Ahshapanek, D. 1962. Phenology of a native tall-grass prairie in central Oklahoma. Ecology 43:135-138.

Beatley, J.C. 1974. Phenological events and their environmental triggers in Mojave Desert ecosystems. Ecology 55:856-863.

Buffington, L.C., and C.H. Herbel. 1965. Vegetation changes on a semidesert grassland range from 1858 to 1963 . Ecol. Mongr. 35:139-164.

Bullock, H.E., Jr., and R.E. Neher. 1980. Soil survey of Dona Ana County area of New Mexico. SCS, USDA in cooperation with BLM and New Mexico Agr. Exp. Sta.

Cable, D.R. 1971. Growth and development of Arizona cottontop [ Trichachne californica (Benth.) Chase]. Bot. Gaz. 132:119-145.

Caprio, J.M. 1966. Pattern of plant development in the western United States. Montana Agr. Exp. Sta. Bull. 607.

Caprio, J.M. 1971. The solar-thermal unit theory in relation to plant development and potential evapotranspiration. Montana Agr. Exp. Sta. Circ. 251.

Chu, A.C.P., H.G. McPherson, and G. Halligan. 1979. Recovery growth following water deficits of different duration in prairie grass. Australian J. Plant Physiol. 6:255-263.

Costello, D.F. 1939. Weather and plant-development data as determinants of grazing periods on mountain range. USDA Tech. Bull. 1190.

Dickinson, C.E., and J.L. Dodd. 1976. Phenological pattern in the shortgrass prairie. Amer. Midl. Natur. 96:367-378.

Evans, M.W. 1940. Developmental morphology of the growing point of the shoot and the inflorescence in grasses. J. Agr. Res. 61:481-520.

Finnerty, D.W., and D.L. Klingman. 1962. Life cycles and control studies of some weed bromegrasses. Weeds 10:40-47.

Frank, A.B., and L. Hofmann. 1989. Relationship among grazing management, growing degree-days and morphological development for native grasses on the Northern Great Plains. J. Range Manage. 42:199-202.

Gilbert, E.F. 1961. Phenology of sumacs. Amer. Midl. Natur. 66:286-300. Haun, J.R. 1973. Visual quantification of wheat development. Agron. J. 65:116-119.

Herbel, C.H., F.N. Ares, and R.A. Wright. 1972. Drought effects on a semidesert grassland range. Ecology 53:1084-1093.

Herbel, C.H., and R.P. Gibbens. 1987. Soil water regimes of loamy sands and sandy loams on arid rangelands in southern New Mexico. J. Soil and Water Conserv. 42:442-447.

Hulbert, L.C. 1963. Gates' phenological record of 132 plants at Manhattan, Kansas, 1926-1995. Kans. Acad. Sci. 66:82-106.
Hyder, D.N., F.A. Sneva, and V.H. Freed. 1962. Susceptibility of big sagebrush and green rabbitbrush to 2,4-D as related to certain environmental, phenological, and physiological conditions. Weeds 10:288-295.

Lieth, H., and J.S. Radford. 1971. Phenology, resource management, and syngraphic computer mapper. Bioscience 21:62-69.

MeCarty, M.K. 1986. A fifteen-year phenological record of pasture plants near Lincoln, Nebraska. Weed Sci. 34:218-224.

McCarty, M.K., and C.J. Seifres. 1969. Life cycle studies with musk thistle. Nebraska Agr. Exp. Sta. Res. Bull. 230.

National Oceanic and Atmospheric Administration. 1987. Climatological data, New Mexico, March. Vol. 91, No. 3.

Nelson, A.B., C.H. Herbel, and H.M. Jackson. 1970. Chemical composition of forage species grazed by cattle on an arid New Mexico range. New Mexico State Univ., Agr. Exp. Sta. Bull. 561.

Paulsen, H.A., Jr., and F.N. Ares. 1962. Grazing values and management of black grama and tobosa grasslands and associated shrub ranges of the Southwest. USDA, Forest Service Tech. Bull. 1270.

Rice, E.L. 1950. Growth and development of five species of range grasses in central Oklahoma. Bot. Gaz. 111:361-377.

Roundy, B.A., J.A. Young, and R.A. Evans. 1981. Phenology of salt rabbitbrush (Chrysosthamus nauseous ssp. consimilis) and greasewood (Sarcobatus vermiculatus). Weed Sci. 29:448-454.

Thornthwaite, C.W.1952. Climate in relation to planting and irrigation of vegetable crops. p. 290-295. In: Proc. VIIIth Gen. Assem.-XVIIth Congr. Internat. Geographical Union, Washington, D.C.

Went, F.W. 1949. Ecology of desert plants. II. The effect of rain and temperature on germination and growth. Ecology 30:1-13.

West, N.E., and R.W. Wein. 1971. A plant phenological index technique. Bioscience 21:116-117.

White, L.M. 1979. Relationship between meterorological measurements and flowering of index species to flowering of 53 plant species. Agr. Meterorol. 20:189-204.

Young, J.A., and R.A. Evans. 1974. Phenology of Chrysothamnus viscidiflorus subspecies viscidiflorus (Hook.) Nutt. Weed Sci. 22:469-475. 